\title{
TEACHING GOD'S WORD - PERENNIAL SOURCE OF ORTHODOXY
}

\author{
Nicolae-Coriolan DURA*
}

\begin{abstract}
Modern man more than ever needs proofs for everything. The $21^{\text {st }}$ century has become the bearer of this tendency. In a world of the modern and of an original democracy, every single person who belongs to the society is becoming a bearer of this feeling of incertitude and his own incertitude is transferred to the level of a whole generation. The subject of the present article is meant to analyze in an unambiguous frame the permanent search for personal identity, while trying to offer direction to where contemporary man could find the proper answers to his inner concerns.
\end{abstract}

Key words: teaching, preaching, canon, keeping the faith.

Information represents for modern man the main source for the elements that govern his life. It is rather difficult in a world of mass media to get the necessary information which should make you believe there is one more source of information that might help you govern your entire existence. The internet, the cable television, smartphones, tablets, advanced technology, despite being created for man, come little by little to subdue the one who has created them. Machinery is useful to man, but each of the invented ones has a different technological language. So many machines so many technologies and so many languages. All of them created for man or to rob man of his right to life and to humanity. In order to be modern or up-to-date, man, instead of making his own life, comes to live in a series of endless impersonal and plain programmes. He has no choice. His choices are forced upon him in staggering rhythm and system. Technology comes to dictate instead of man. They speak about the speed

* PhD, Rev., Lecturer, Faculty of Orthodox Theology at "1 Decembrie 1918" University, Alba Iulia, Romania. 
of internet and of the information which man might have at his disposal. An uninformed man is suspiciously regarded in the society, is driven aside. Words like: "Are you the only one who hasn't heard about..?" or "What?!? Don't you know about?" are well-known to the young generation of the 'modern' world.

\section{Some questions and answers for the man of the $21^{\text {st }}$ century concerning 'the modern of this century', and especially in connection to 'the modern of the orthodoxy'.}

First of all, the problem of being 'modern' or not is a false as concerning man. We just cannot think of man as being 'modern' or 'nonmodern' (i.e., old-fashioned). Man just must be one thing, namely 'man'. We could talk about any profession a man may practice: the man as a teacher, the man as a doctor, etc. Since early childhood a system makes him choose a profession, get trained for it, become the best in his field so that he should be successful in life. So much sacrifice just to fulfill one's 'dream'. But, unfortunately that dream will only be devised within a material world. It might be said that 'the modern' of the surrounding world only offers the man an empty dream for a temptation he has been imbued with. The idea is not a new one, for, in the garden of Eden, the tempter offered the man, for the first time, something he did not long for, giving him the illusion of getting something he already owned. We could say that the 'modern' concept of 'marketing' is in fact so old. The devil is the best marketing agent as he succeeds in persuading people to wish for what in fact they do not, and afterwards to make them put into practice this fake wish just to get hold of something useless. This phenomenon is identical to that of the New Testament, for tempting our Saviour Jesus Christ was developed in a similar frame. We might go deeper concerning this issue if we think of the parable of the prodigal son our Saviour gave us, as this is a realistic example for someone's wish to be 'modern'.

There is another terrible reality we have to consider; namely, the fact that the illusion of this outer, material aspect of the modern will only have one final issue: disillusion. This ultimate result could only be postponed by keeping 'the modern' up to date, that is by permanently changing the offer. While the slogan for the 'modern' of the present times seems apparently new, in fact it is so old, i.e.: 'take advantage'. All of 
reality is assaulted by this message. An entire range of such marketing exists, beginning with shelves in shops displays=ing goods, visual advertising or written in the press, on buildings, streets or means of transport etc. Everything has one purpose: man must never be left alone. Man must not become a man and, in particular, he must not become human. When he is left alone, man realizes that he has a choice of what he wants or not from his life and, especially, he comes to the conclusion that this life is his own. Could we imagine and understand the astonishment of a child, a product of the 'modern' society, who, while being on a trip with his parents and admiring a sunset in a blue sky, is not interrupted by anyone after twenty minutes presenting ads for medicines, toothpaste, engine oil or floor varnish.

After disillusion, there comes the next stage: getting confused. 'Modern' man becomes betrayed in his expectations, in his trust put in the 'modern' and in the direction shown by 'most of them' (the majority). He realizes that "there is nothing new under the sun" (Ecclesiastes 1,9). Persisting in searching for support where there is none, man comes to the next stage, that of the vengeance, revenge, the wish to get even. The stage is characterized by total negativism against everyone and everything, a stage where he is looking for the guilty he could revenge himself on. There are a great number of reasons: for his stolen life, for his deceived feelings and hopes. Now the whole world and all the people are guilty, anyone may be considered guilty except his own person. These will be two ways of solving his soul's conflict. One can be the final surrender without any honest desire to get up again (this is the case of Judas Iscariot), and the second is to acknowledge the failure of one's way which led to nowhere, to give it up and to look for a different one. Here we find the cause of the Apostle Peter, who after the denial of Christ "went outside and wept bitterly" (Luke 22,62) or that of Saul of Tars who came to Damascus after meeting Christ the resurrected and "for three days he was blind and did not eat or drink anything" (Acts 9, 8-9). To enjoy finding such a way is not at hand for everyone but just for those who are looking for it implies through such perseverance that the man wanted to find it by any means (Matth. 11, 12). The way is unique and it was shown by Our Saviour Jesus Christ when he said: "I am the way and the truth and the life" (John 14, 6) emphasizing man's freedom to choose: "If 
anyone would come after me he must deny himself and take up his cross and follow me" (Matth. 16, 24), some freedom no one is allowed to deny.

The same way, a teaching-learning system implies a subject to be taught, teaching staff willing to teach and share their knowledge, as well a disciple that can be taught or shared. The process of acquiring knowledge depends upon the desire to learn each disciple. One can be very responsible in acquiring knowledge, while the other may be less responsible, thus acquiring less knowledge from what they are being taught. The picture of the present reality is to be found in the Old Testament when God, through his chosen man Moses, teaches the people of Israel by His commandments to be obeyed in order to live a pure life (Deut. 5, 1; 6, 1; 17, 19; 31, 13). If we take a look at the New Testament, we shall see a stage-like schooling like the system foreshadowed by the Old Testament ${ }^{1}$. Firstly, we must keep in mind the image of John the Baptizer, teaching on the banks of the Jordan those who 'wanted to be in fashion', a tough lesson in connection to the rush for the 'big nothing': "You brood of vipers! Who warned you to flee from the coming wrath?" (Matth. 3, 7; Luke 3,7). What was taught by John the Baptizer was meant for everyone but it was effective only on some of them; i.e., on those who were really looking for an answer to this problem.

Some of them followed him and eventually became his disciples, being thus privileged to receive the prophet's teaching and also to assimilate what they had been taught. Testimony for this remains the moment when, after John the Baptizer's had been murdered, his apostles "gathered around Jesus and reported to him all they had done and taught (Mark 6, 30)". How did they hand over that teaching, that new founding in a world without printing machines, so without books or notebooks, let alone any possibility of multiplication. Teaching was accomplished by word of mouth; its contents being entrusted to each person. We think it appropriate to mention that he addressed tax collectors in one way (Luke 3,12 ), soldiers another way (Luke 3,14), the Pharisees and Sadducees in yet another way, and the crowds quite differently (Luke 3, 10).

Others, being just formalists and wanting to be 'modern', come to John the Baptizer and questioned him: "Why then do you baptize if you

1 Samir Gholam, "Legea divină și Legea bisericească”, in Studii Teologice, no. 910/1975, p. 750-751. 
are not the Christ, nor Elijah, nor the Prophet?" (John 1, 19-20).

In other more modern words: "Why do you want to produce a new trend, the trend of repentance?", or "Why do you want us to be modern?"

\section{What makes the unique aspect of the teaching our Saviour Jesus Christ entrusts us with?}

When our Saviour Jesus Christ began preaching, the mission of Saint John the Baptizer ceased. The people were prepared to receive the true teaching. Identifying himself as being "the good shepherd" (John 10, 11), the Saviour is addressed as 'Rabbi' by his disciples (John 1, 38-39) and the old member of the Sanhedrin, Nicodemus calls Him the same (John 3, 2) or 'teacher'. This is an aspect emphasized in the garden of Ghetsemane, where Jesus resurrected appears to Mary Magdalene (John 20, 16) and when our Saviour meets Nathanel (John 1, 49). The identification of our Saviour as the unique Shepherd is meant to identify His sheep for: "My sheep listen to my voice, I know them and they follow me. I give them eternal life, and they shall never perish, no one can snatch them out of my hand" (John 10, 27-28).

The fact that, while in the garden of Eden, God presented the first people with the true and unique teaching, does not mean that the tempter could not come to sow the seeds of the apparently 'true' teaching. The beneficiary of his teaching, i.e., man, was free to choose.

The presence of false prophets, of false priests or of wizards together with gods or deities made up by the human mind is to be found throughout the old testamentary history. The true and unique teaching needed to be kept in a polytheistic world, especially by truthful prophets and judges chosen by God.

Both the true teaching and the false one found their representatives willing to hand it over. A typical saying of our times asserts that "offer always depends on demand; when there is no demand on the market, the offer fades away". Thus, we could explain why, on Mount Carmel offerings, there was "only one of the Lord's prophets left (Elijah), but Baal has four hundred and fifty and four hundred prophets of Asherah" (I Kings, 18-22).

Their presence as well as their deceiving teachings were spread among the people. This reality was emphasized by our Saviour Jesus 
Christ both directly when he says: "go and learn what this means: 'I desire mercy, not sacrifice"” (Matth. 9, 13), “...Woe to you, teachers of the law and Pharisees, you hypocrites! You travel over land and sea to win a single convert, and when he becomes one, you make him twice as much a son of hell as you are" (Matth. 23, 13-39). And indirectly, when he told his disciples: "...be on your guard against the yeast of the Pharisees and Sadducees (Matth. 16, 6)".

Besides identifying and setting aside false teachings, , our Saviour is concerned with spreading the true teaching first of all to the crowds (Matth. 5-7), and then to his disciples and Apostles "as one who had authority, and not as their teachers of the law" (Matth. 7, 29), in the synagogues (Matth. 13, 54; Mk. 11, 17; 12, 31), on the sea shore (Mk 2, 13), in the temple (Matth. 21, 23; Luke 20, 1), from a boat (Luke 5, 3), on the Sabbath (Luke 13, 10), on the Mount of Olives (John 8, 2), in Jerusalem, in Galilee, in Samaria, in the Canaan country, in Capernaum (Luke 4, 3) in his homeland (Mk 13, 54). In time, testimony was given the episode of Annas, the high priest, questioning Jesus, to whom our Saviour said: "I have spoken openly to the world. I always taught in synagogues or at the temple, where all the Jews come together. I said nothing in secret" (John 18, 20).

Similarly, he is concerned about training those to whom His is to hand over His true teaching. The mission to do that is entrusted to the Holy Apostles. They are chosen from his disciples when, on climbing up the mountain he "called to him those he wanted, and they came to him. He appointed twelve - designating them apostles - that they might be with him and that he might send them to preach" (Mk. 3, 13-14). At first, he sent them on a trial telling them: "as you go, preach this message..." (Matth. 10, 5-7), and then after being filled with power from Heaven to go to all nations to preach them the true teaching and how to live a clean life: "Therefore go and make disciples of all nations, baptizing them in the name of the Father and of the Son and of the Holy Spirit, and teaching them to obey everything I have commanded you. And surely I am with you always, to the very end of the age".

What was it that our Saviour Jesus Christ taught the Apostles, the disciples and the crowds? How could one explain the fact that the four gospels (of which three are synoptic), or, more precisely 89 chapters from 
it comprise the public activity of their teacher, an activity that took place in a period of three years according to the calendar? What exactly did Our Saviour Jesus Christ teach, when most of his speeches were circumstantial speeches, triggered by a special context or by the individual curiosity of a listener? What, how and especially about what did our Saviour speak? Equally, we should ask ourselves how much of the things taught by the Teacher could have been preserved, taking into account the fact that the aim of our Saviour was not to write his memories, nor was the intention of the Apostles to write down a thorough history of the Saviour's speeches or acts. We can realize this fact simply from a few episodes that put a sign on the existence of some people who knew our Saviour. Let's take the conversation between our Saviour Jesus Christ and old Nicodemus, in the twilight, just the two of them - how much of it did the Evangelist Luke succeed in writing down and how much was transmitted by word of mouth? Let alone the other episodes like the conversation of our Saviour with the woman from Samaria, or with Mary Magdalene (after the resurrection), when there was no witness present. The only record found to enlighten this aspect is Saint John's, the Evangelist's assertion: "Jesus did many other things as well. If every one of them were written down, I suppose that even the whole world would not have room for the books that would be written" (John 21, 25). The aim is also defined by the same evangelist when he says: "But these are written that you may believe that Jesus is the Christ, the Son of God, and that by believing you may have life in his name" (John 20, 31).

\section{The teaching of the Orthodox treasury in the Apostolic period}

After the Holy Ghost Descended over the Apostles on Pentecost, they were able to hand on the uniqueness of the true teaching. Luke, the Evangelist, writes his first book with the clear intention to speak: "I wrote about all that Jesus began to do and to teach" (Acts 1, 1). Just one book comprising 28 chapters offers a clear image of how the teaching/ preaching of the revealed word took place after the Ascension to Heaven of our Saviour Jesus Christ. From the richness of its contents, we find that from the very beginning the first Christians, together with the Apostles, devoted themselves to 'teaching' (Acts 2, 42) endeavouring to fulfill the mission they received. At first, we find them teaching this treasury at the 
temple of Jerusalem (Acts 5, 21; 5, 25; 5, 28). The effect of preaching the new teaching among the Jews is a violent one. The priests and the captain of the temple guard and the Sadducees came up to the Apostles (Acts 4, 1), and then they were questioned (Acts 4, 7), threatened (Acts 4, 21), flogged (Acts 5, 40) and put in the public jail $(5,18)$. The Sanhedrin with the high priest wanted to put them to death (Acts 5, 33). The execution of Saint Archdeacon Stephen was not enough. King Herod approved of this violence and cruelty, for after a short while he had James, the brother of John, put to death with the sword and when he saw that this pleased the Jews, he proceeded to seize Peter too (Acts 12, 2-3), whom he put in prison to be killed.

As a result of those events "all except the apostles were scattered throughout Judea and Samaria” (Acts 8, 1).

The period of molding Paul into the future Apostle Paul is crucial for understanding how the teaching of the true faith was done. He was to spend two years in Arabia, being taught or getting the revelation from Christ himself. Could it be just be chance that Saint Apostle Paul and Barnabas spent one year in Antioch teaching great numbers of people? The effect was written down in the same book, for "the disciples were called Christians at Antioch" (Acts 11,26). During his missionary travels Saint Apostle Paul together with his assistants were presenting the Christian teaching to all those willing to know it (see his preaching at the meeting of the Areopagus - Acts 17, 19), as well as to those willing to put it into practice (see the communities founded by Apostle Paul and Barnabas).

This period was not spared false teachings, as we have the cases of Ananias and Sapphira, the sorcerer Simon of Samaria which bear testimony beyond time. To these are to be added the endeavours of Jewish Christians to preach false teachings that came from within the Christian communities (Acts 15,11), as well as the danger that came from outside the Christian communities, from the part of the Judaic proselytes ${ }^{2}$.

For as long as Apostle Paul and his assistants were present and could defend young communities, the young communities were spared the danger of being exposed to false teachings. The fact is mentioned by

2 Sabin VerZAN, "Cîrmuirea bisericii în epoca apostolică", in Studii Teologice, no. 56/1952, p. 337-351. 
Saint Apostle Paul when, while being with the community of Miletus, he bids farewell to all the priests from Ephes, Miletus and from their neighbourhood, warning them that after his leave the true teaching will be hit from two sides: from the inside and from the outside. More precisely, the Apostle says: "I know that after I leave, savage wolves will come in among you and will not spare the flock. Even from your own number men will arise and distort the truth in order to draw away disciples after them" (Acts 20, 29-30).

\section{The true teaching among the Pauline epistles}

In his epistle to the Romans Saint Apostle Paul has a parental attitude giving advice: "I urge you brothers, to watch out for those who cause divisions and put obstacles in your way that are contrary to the teaching you have learnt. Keep away from them" (Rom. 16, 17). His addresses to the community from Philippi are harsher than ever: "Watch out for these dogs, those men who do evil, those mutilators of the flesh" (Philip 3, 2).

The content of the Pauline epistles reveal an impressive relationship between he who gave them birth into Christ and the communities born out of Saint Apostle Paul's endeavor. His paternal, caring attitude is to be found in the messages sent in a written form and preserved till today. Not rarely the Apostle refers to the way they received the Gospel and to the person who taught them. The Thessalonians he addresses in his second epistle by telling them: "stand firm and hold to the teachings we passed on to you, whether by word of mouth or by letter" (II Thess. 2, 15). Timothy is addressed by the words: "devote yourself to the public reading of Scripture, to preaching and to teaching" (I Tim. 4, 13), "watch your life and doctrine closely" (I Tim. 4, 16), which means that we make no mistake if we assert that the Apostle followed Christ focusing his missionary activity in two directions: the first one, following the preaching of the evangelic word to the whole community, and the second one, having in view individuals who were then placed to be at the head of communities ${ }^{3}$.

Testimonies like: "whatever you have learnt or received or heard

${ }^{3}$ Mircea IOAN, "Preoția harică și preoția obștească”, in Ortodoxia, no. 2/1979, p. 249. 
from me, or seen in me - put into practice" (Philip. 4, 9) or “... finally, brothers, we instructed you how to live in order to please God... now we ask you in the Lord Jesus to do this..." (I Tess. 4, 1), and "...for you yourselves have been taught by God (I Tess. 4, 9), come to complete what was already said above. As concerning the individual urge, Timothy and Titus are eloquent images of the above-mentioned aspects. Thus, Timothy is urged "to devote himself to the public reading, preaching and teaching" (I Tim. 4, 13), "correctly handling the word of truth (II Tim. 2, 15), for "the Lord's servant must be... able to teach" (II Tim. 2, 24), for he "knows from whom he learnt it" (II Tim. 3, 14), and "...you, however know all about my teaching" (II Tim. 3, 10).

Similarly, the individual urge addressed to his assistants concerns those who are ministered by them, for the Apostle says "Why should the true teaching" (I Tim. 4, 6) superior to "the teaching of the demons" (I Tim. 4,1 ) or to that of those who do not know what they are talking about" (I Tim. 1, 7). The first argument is given by Saint Apostle Paul in his epistle to the Galatians when he says: "the gospel I preached is not something that man made up. I did not receive it from man, nor was I taught it; rather I received it by revelation from Jesus Christ (Gal. 1, 1112), and the second argument we can find in the individual testimony of the Holy Fathers of the church.

\section{5. 'Teaching' as revealed in the canons of the Holy Fathers according to the orthodox canonical testimony}

The unanimously acknowledged orthodox canonical testimony in time offers a wide image of the orthodox way of understanding the term of 'teaching' (by tradition) $)^{4}$. The first patristic testimony preserved was given by the Holy Father Peter, archbishop of Alexandria ( $\uparrow 311)$ who, in canon 15, offers the following advice concerning fasting on Wednesdays and Fridays: "nor will anyone find fault with us for fasting on them... it is enjoined upon us according to the tradition..." . And Holy Athanasius the Great $(\dagger 373)$, referring to the consideration due to the contents of the

\footnotetext{
${ }^{4}$ Ioan I. ICĂ jr., Canoanele ortodoxiei, vol. I, (Canonul Apostolic al primelor secole), cap. XXI. Despre predania Sfântului Botez, Sibiu, Deisis, 2008, p. 580-582.

${ }^{5}$ Canon 15 apud Nicodem Milaș, Canoanele Bisericii Ortodoxe, însoțite de comentarii, vol. II, $2^{\text {nd }}$ part, Arad, Tipografia Diecezană, 1936, p. 26.
} 
Holy Scriptures asserts that "they were taught by tradition by the Holy Apostles, by those who witnessed them from the beginning and were servants of the Word... being advised by the true brothers and taught to consider them canonical books taught by tradition" "..., thus all the books of the Old Testament being 22 in number. For this "was the number taught..."7.

The testimony of the times when the church was getting out of a period of persecution and was enjoying the freedom to give testimony of its teaching, was completed by Saint Basil the Great († 379), who, as regarding the baptism of the Cathari, asserts the following: "What ground is there, then, for the acceptance of the baptism of men who baptize into the Father and the Son and Montanus or Priscilla? For those who have not been baptized into the names delivered to us have not been baptized at all" . The same Holy Father as regarding the fornication of the clerics, especially that of the deacons, asserts: "We ought therefore to know both what is of exact prescription, and what is of custom; and, in cases which do not admit of the highest treatment, to follow the traditional direction" . During his period two main sources of the Orthodox Christian teaching appear: both written and unwritten. Both of them are of the same importance, one being supported by the other. Thus, when it comes to trigamy, the way to find the right answer is supported by the sources themselves while asserting the superiority of tradition, as the written source could not contain the whole unwritten source from where it gets its content. Here is the testimony of canon 87: "So about the importance of these things, we ought to mention at first our custom, which has the power of law, for the laws have been given to us by the holy men"10.

In canon 91, Saint Basil the Great offers the clear image both of the written source and that of the unwritten one, indicating the fact that both of them have the same origin:

${ }^{6}$ Canonul 2, apud Pidalion sau Cârma bisericii, Iași, Credința strămoșească Ph, 2013, p. 593.

${ }^{7}$ Canonul 2, apud Nicodem Milaș, op. cit., p. 28-30.

8 Canonul 1, apud AndreIU, Baron de Şaguna, Enchiridion, Sibiiu, Tipografia archidiecesana, 1871, p. 397.

${ }^{9}$ Canonul 3, apud Ioan N. FlocA, Canoanele Bisericii Ortodoxe, Sibiu, Tipografia S.C. Lumina Tipo, 2005, p. 235.

${ }^{10}$ Canonul 87 apud Andreiu, Baron de Șaguna, Enchiridion..., p. 441. 
"Of the beliefs and practices whether generally accepted or publicly enjoined which are preserved in the Church, some we possess derived from written teaching; others we have received delivered to us in a mystery by the tradition of the Apostles; and both of these in relation to true religion have the same force. And these no one will gainsay - no one at all events, who is even moderately versed in the institution of the Church. For where we attempt to reject such customs as have no written authority on the ground that the importance they possess is small, we should unintentionally injure the Gospel in its very vitals; or rather should make our public definition a mere phrase and nothing more"11.

"Who is thence who has taught us in writing to sign with the sign of the cross those who have trusted in the name of our Lord Jesus Christ? What writing has taught us to turn to east at the prayer? And we bless both the water of the baptism and the oil of unction, and even the very person who is baptized. Out of what Scripture? Is it not an account of the silent mystical tradition? The very anointing with oil itself, what written record has taught? And whence received we the custom that the man should be thrice immersed? And the rest of ceremonies in baptism, as the renouncing of the devil and his angels whence have we...?"12.

If the explanations of Saint Basil the Great offered in his canon have not been enough, we shall find more explanations in canon 92. This last canon attributed to Saint Basil the Great and recognized by the fundamental collection of canons comes to complete an image of the epoch and of the geographical area which the author of the canon knew so well. We cannot keep silent the fact that Saint Basil the Great was in correspondence with public and religious personalities of his times, a fact that grants canon 92 a special role and importance. Here is the content of the canon: "And if doxology 'with the Holy Ghost' is neither witnessed nor written, we say it should not be received if nothing else unwritten is not received; and if most of the mystical have been established among us in an unwritten way, then this one shall be received together with the others. But I consider that the apostolic procedure shall be to stick with the unwritten", "I praise you", it is said 'that ye remember me in all things, and keep the ordinances as I delivered them to you' (I Cor. 11, 2); and again "Hold fast the traditions which ye have been taught whether by

${ }^{11}$ Canonul 91 apud Nicodem MiLAș, op. cit., p. 127-138.

${ }^{12}$ Canonul 91 apud Ioan N. Floca, Canoanele Bisericii Ortodoxe..., p. 267. 
word, or our Epistle" (II Tess. 2, 15). One of these traditions is the practice which is now before us, which they who have ordained from the beginning, rooted firmly in the churches, delivering it to the successors, and its use through long custom advances pace by pace with time. If, as in a court of Law, we were at a loss for documentary evidence, but were able to bring before you a large number of witnesses, would you not give your vote for our acquittal? I think so. "For the mouth of two or three witnesses shall the matter be established?" (Deut. 19, 15). And if we could prove clearly to you that a long period of time was in our favour, should we not have seemed to you to urge with reason that this suit ought not to be brought into court against us? For ancient dogmas inspire a certain sense of awe, venerable as they are with a hoary antiquity ${ }^{13}$. The canons of Saint Basil the Great will have legislative value considering both the importance of the subject treated and the importance of the author, as his canonical point of view will be taken over by the ecumenical synods V$\mathrm{VI}$ in canon $32^{14}$.

Saint Gregory of Nyssa is confronted with another problem for which he has to find a solution. Despite the fact that this problem emerged in an apparently different field, that of digging of graves, robbery, usury, as well as sacrilege, the solution to the problem is to be found in the same treasury as in canon 8 of Saint Gregory of Nyssa. Here, we find the following assertion: "all these may consider passions for the Fathers have taught us so" $"$. Canon 8 of the same Holy Father of the Church tries to find a solution to the sin of sacrilege, and both the gravity of the sin and the right penance are seen by Saint Gregory of Nyssa as follows: "as the tradition of the Fathers established the penance in this situation in a shorter time than for adultery. As for the kind of sin, first of all is taken into account the fact that we should consider the heart disposition of the one to be healed and no one should think that time alone could heal (no healing needs just time), but the disposition of the one who wants to heal himself through faith"16.

The iconoclastic period, characterized by theological fights inside

${ }^{13}$ Canonul 9, apud Nicodem Milaș, op. cit., p. 147.

${ }^{14}$ G. D. Boroianu, Dreptul bisericesc, Iași, Tipografia Dacia, 1899, p. 112.

${ }^{15}$ Canonul 6, apud Pidalion ..., p. 669.

${ }^{16}$ Canonul 8, apud Pidalion..., p. 671. 
the Church, offers us through the superior of the monastery Studion, having as its patron 'St. John the Baptizer', a testimony rising from this neighbourhood of the imperial capital, Constantinople. In the answer to the eighth question, Saint Theodore the Studite (759- 826), when asked if there is any custom regarding the monastic brothers who used to communicate with anyone and pray and eat together with them, he refers to the traditions received from old times and especially to the words used by Saint Apostle Paul in the same context: "we command you, brothers, to keep away from every brother who is idle and does not live according to the teaching you received from us (Tess. 3, 6). For you yourselves know how you ought to follow" 17.

In the time of the Patriarch Nicolas of Constantinople (1086-1111), the problem of fasting before the Assumption of the Virgin Mary was raised, and the answer for question number three reminds us of a synod held at Constantinople under the patriarch Luke (1156-1169), according to the canonist Ioan N. Floca.

"Answering the question how long should they fast, the patriarch Luke says that, even if we do not have anything written about this fastening period alike the Advent, we should follow the 'unwritten tradition' and begin fastening on the $1^{\text {st }}$ august before the Ascension and on the $1^{\text {st }}$ of September for the Advent. This disposition of patriarch Luke was taken into the usage of the Orthodox Church and has been kept so far; the same way we should interpret the answer of patriarch Nicholas"18.

\section{Conclusions}

1. We see that from the very beginning God presented the first men with the true 'Teaching'.

a) The first form of the 'Teaching' was the unwritten one, by word of mouth and later form it derives its second form, the written one;

b) The written form will never comprise the unwritten one

2. With time, man begins to produce his own 'teachings' preferring to guide himself according to them. That's why...

${ }^{17}$ Canonul 8, apud Ioan N. FlocA, Canoanele Bisericii Ortodoxe..., p. 317.

${ }^{18}$ Canonul 3 (question no. 3), apud Ioan N. FloCA, Canoanele Bisericii Ortodoxe..., p. 319. 
c) a) God feels compelled with almost each generation to reveal the content of His 'teaching' through chosen men, in order to keep this 'teaching' clean. This aspect is pointed out by Saint Apostle Paul when he says: "In the past God spoke to our forefathers through prophets at many times and in various ways" (Hebr. 1, 1).

d) b) The difference between God's 'teaching' and the 'teachings' made up by people is obvious for the 'teaching' of God is unique and unchangeable; it is as unique as God himself ${ }^{19}$. This is witnessed by Saint Apostle Paul in his epistle to the Hebrews when he says: "Jesus Christ is the same yesterday and today and forever" (Hebr. 13, 8) and later on: "One Lord, one Faith, one Baptism".

3. God's 'teaching' has become perfect for "in these last days He has spoken to us by His Son, whom He appointed heir of all things, and through whom He made the universe" (Hebr. 1, 2), but the 'teaching' of men is changed according to circumstances, interest, context, person etc. Apostle Paul confesses: "For the time will come when men will not put up with sound doctrine. Instead, to suit their own desires, they will gather around them a great number of teachers to say what their itching ears want to hear. They will turn their ears away from the truth and turn aside to myths" (II Tim. 4, 3-4).

4. The 'teaching' has always meant for the Orthodox Church a source for the value of the true teaching and a treasure inherited directly from our Saviour Jesus Christ, handed over to the Holy Apostles and through these, by apostolic succession to the bishops and the priests till the end of times.

5. The present mission of the Orthodox Church and especially of the Romanian Orthodox Church is that of showing the young generation of today the value of the treasure of the teaching of our Saviour Jesus Christ according to the godly 'teaching'. Only if it is connected to this 'teaching', will the teaching preached in this era prove to be true and liberating/useful to the 'modern' man. We understand by this ample process

"not only the external process of teaching certain prescriptions from

${ }^{19}$ Grigore T. MARCU, "Unitate și diversitate în Noul Testament și în Biserica primară”, in Mitropolia Ardealului, no. 7-9/1979, p. 584-588. 


\section{$16^{\text {th }}$ International Symposium on Science, Theology and Arts (ISSTA 2017)}

one epoch to another or from one church to another, but especially strictly and successively keeping the fundamental principles of the universal Church, as both faith and church administration are regarded, principles which have been established by the Founder of the Church Himself and, after Him, by those who organized the Church and founded the pastoral office" 20 .

\section{References}

1. Boroianu, G. D., Dreptul bisericesc, Iași, Tipografia Dacia, 1899.

2. FlocA, Ioan N., Canoanele Bisericii Ortodoxe, Sibiu, Tipografia S.C. Lumina Tipo, 2005.

3. GHOLAM, Samir, "Legea divină și Legea bisericească”, in Studii Teologice, 1975, no. 9-10.

4. ICĂ, Ioan I. jr., Canoanele ortodoxiei, vol. I (Canonul Apostolic al primelor secole), Sibiu, Deisis-Stavropoleos, 2008.

5. IOAN, Mircea, "Preoția harică și preoția obștească", in Ortodoxia, no. 2/1979.

6. MARCU, Grigore T., "Unitate și diversitate în Noul Testament și în Biserica primară", in Mitropolia Ardealului, no. 7-9/1979, p. 584-588.

7. MiLAȘ, Nicodem, Canoanele Bisericii Ortodoxe, insoțite de comentarii, vol. II, $2^{\text {nd }}$ part, Arad, Tipografia Diecezană, 1936.

8. MILAȘ, Nicodem, Dreptul bisericesc oriental, București, Tipografia "Gutemberg", 1915.

9. *** Pidalion sau Cârma bisericii, Iași, Credința strămoșească $\mathrm{Ph}, 2013$.

10. ȘAGUNA, Andreiu, Enchiridion, Sibiiu, Tipografia archidiecesana, 1871.

11. VERZAN, Sabin, "Cîrmuirea Bisericii în epoca apostolică", in Studii Teologice, no. 5-6/1952, p. 337-351.

${ }^{20}$ Nicodem MiLaș, Dreptul bisericesc oriental, București, Tipografia "Gutemberg", 1915 , p. 35. 